\title{
Seed Characterization and
} Relationships between Seed and Cotyledon Properties in Lagenaria spp. Accessions

\author{
Nebahat Sari \\ Department of Horticulture, Cukurova University, 01330, Adana, Turkey
}

\section{Emily Silverman, Danny Reiland, and Todd C. Wehner \\ Department of Horticultural Science, North Carolina State University, Raleigh, NC 27695-7609}

Additional index words. correlation, cotyledon length and width, descriptor, genetic resources, seed weight length and width

\begin{abstract}
Bottle gourd [Lagenaria siceraria (Molina) Standl.] is widely produced in some Asian and African countries as a fresh vegetable as well as for seed consumption. A major use of bottle gourd is for rootstocks in grafted watermelon production. There are several centers where bottle gourd genetic resources are maintained, with the U.S. Department of Agriculture (USDA) germplasm collection being one of the most important. There is little published information on the relationship between seed morphology and the early establishment of seedlings in bottle gourd. The objective of this study was to determine seed characterization, morphology, and cotyledon shape in 163 Lagenaria spp. accessions and measure any relationship between seed and cotyledon characteristics. In USDA Lagenaria germplasm, it has been determined that the common character in seeds was medium in terms of seed size (53\% of accessions), intermediate in seed surface lustre $(39 \%$ of accessions), brown in seedcoat color $(89 \%$ of accessions), thin and uniform in seed margin (35\% of accessions), and tan in seed margin color (64\% of accessions). According to the research results, seed weight ranged from $0.11 \mathrm{~g}$ (PI 500820) to $0.36 \mathrm{~g}$ (PI 675112), seed length from $13.17 \mathrm{~mm}$ (PI 500820) to $23.68 \mathrm{~mm}$ (PI 675112), and seed width from 5.86 (PI 500808) to $11.21 \mathrm{~mm}$ (PI 491274). Cotyledon length ranged from 5.46 cm (PI 368640) to $2.47 \mathrm{~cm}$ (PI 381850). The widest cotyledon was $3.00 \mathrm{~cm}$ (PI 534552), and the narrowest was $1.50 \mathrm{~cm}$ (PI 381831). Interesting correlations were observed for seed weight with seed length $\left(R^{2}=0.259\right)$, and cotyledon length with cotyledon width $\left(R^{2}=\right.$ 0.547).
\end{abstract}

Bottle gourd is one of the first plant species domesticated for human use (Clarke et al., 2006; Schlumbaum and Vandorpe, 2012). Bottle gourd fruits are consumed as a vegetable in some African and Asian countries. Immature fruits are eaten after being cooked in the same way as Cucurbita spp. Mature fruits are scraped clean, and the dried, hard rind is used in making bowls, containers, musical instruments, decorations, and even fishing floats. Shoots, tendrils, and leaves of bottle gourd plants are also consumed by cooking (Manandhar, 2002; Moerman,

\footnotetext{
Received for publication 5 Nov. 2020. Accepted for publication 19 Nov. 2020.

Published online 23 December 2020.

We appreciate the U.S. Department of Agriculture for supplying Lagenaria accessions, NC State University Phytotron for providing greenhouse facilities, and Berken Cimen from Cukurova University, Turkey, for his contributions to the statistical analysis.

N.S. is the corresponding author. E-mail: nesari@ cu.edu.tr.

This is an open access article distributed under the CC BY-NC-ND license (https://creativecommons. org/licenses/by-nc-nd/4.0/).
}

1998). Some bottle gourd types are mainly grown for edible seeds (Achigan-Dako et al., 2008). Lagenaria seeds are good sources of lipids and proteins (Achu et al., 2005; Loukou et al., 2007). There is a considerable interest in bottle gourd seeds because of their high nutritional quality, mainly in terms of protein and oil content (Pradhan et al., 2013). Lagenaria siceraria can also be used as a rootstock for watermelon to control soilborne diseases and to manage stress from low soil temperature, excessive water, and salinity stress. Watermelon grafting onto bottle gourd was first used in Korea and Japan in the late 1920s (Ashita, 1927), the gourds having a high compatibility rate with watermelon (Lee, 1994; Oda, 1995; Yetişir and Sari, 2003).

L. siceraria, commonly known as bottle gourd or white-flowered gourd, has high morphological diversity. In its primary and secondary centers of origin, bottle gourd shows great morphological and genetic variability (Given, 1987). Multiple research groups have studied fruit size and shape (Morimoto et al., 2005; $\mathrm{Xu}$ et al., 2014; Yetişir et al., 2008), fruit rind thickness, fruit length, fruit width (Harika et al., 2012; Koffi et al., 2009; Morimoto et al., 2005), seed morphotypes (Morimoto et al., 2005; Yetişir et al., 2008), and other agromorphological characteristics (Achigan-Dako et al., 2008; Morimoto et al., 2005, 2006; Sivaraj and Pandravada, 2005; Xu et al., 2014; Yetişir et al., 2008). A substantial variation among bottle gourd landrace in seed dimensions and seed yield was also reported by Buthelezi et al. (2019). Bottle gourd plants grown in a trailing system produced more seed yield with high quality than the traditional growing system (Sharma et al., 2016).

The most fundamental steps in the conservation and use of plant genetic resources are ensuring efficiency and sustainability in plant production. Seed is the basic tool of sustainability in generatively propagated plant species. Therefore, gene banks have undertaken the task of long-term protection of seeds against the loss of possible genetic diversity in the future. The U.S. Department of Agriculture, Agricultural Research Service (USDA-ARS) has one of the most important genetic resource collections in the world in Lagenaria as well as in many plant species. According to our knowledge, the previous study on properties of $L$. siceraria seed is limited, and there is no study about seed characteristics in the U.S. Genebank. Therefore, the objective of this study was to determine morphological characterization of seeds of bottle gourd genetic resources in USDA-ARS, to measure the quantitative seed characteristics, and to determine the correlations between seed and some seedling traits at the early seedling stage in 163 Lagenaria spp. accessions. This study is also important in that bottle gourds have seed measurements made with the greatest number of genetic resources.

\section{Materials and Methods}

The USDA-ARS, Plant Genetic Resources and Conservation Unit in Griffin, GA (http://www.ars-grin.gov) has 235 PI accessions of $L$. siceraria (Levi et al., 2009). In this study, all bottle gourd accessions in the collection were requested, and seed measurements were made in 163 that germinated from 180 accessions received. The experimental materials represented four continents. The codes and collection locations of 163 bottle gourds accessions used in this study are shown in Table 1 .

Each accession was classified for five important qualitative traits following the standards of the descriptor list published by the Bioversity International for Cucurbitaceae (2007) as seed size (small, medium, large), seed surface lustre (dull, intermediate, glossy), seedcoat color (seedcoat absent, white, tan, yellow, orange, brown, gray, black), seed margin [absent, (Thin and uniform, Th-U), Thin and irregular (Tn-I), Thick and uniform (Tk-U), Thick and irregular (TkI)], seed margin color (seed margin absent, white, tan, yellow, orange, brown, gray, black). Ten seeds of each accession were measured for the following morphological 


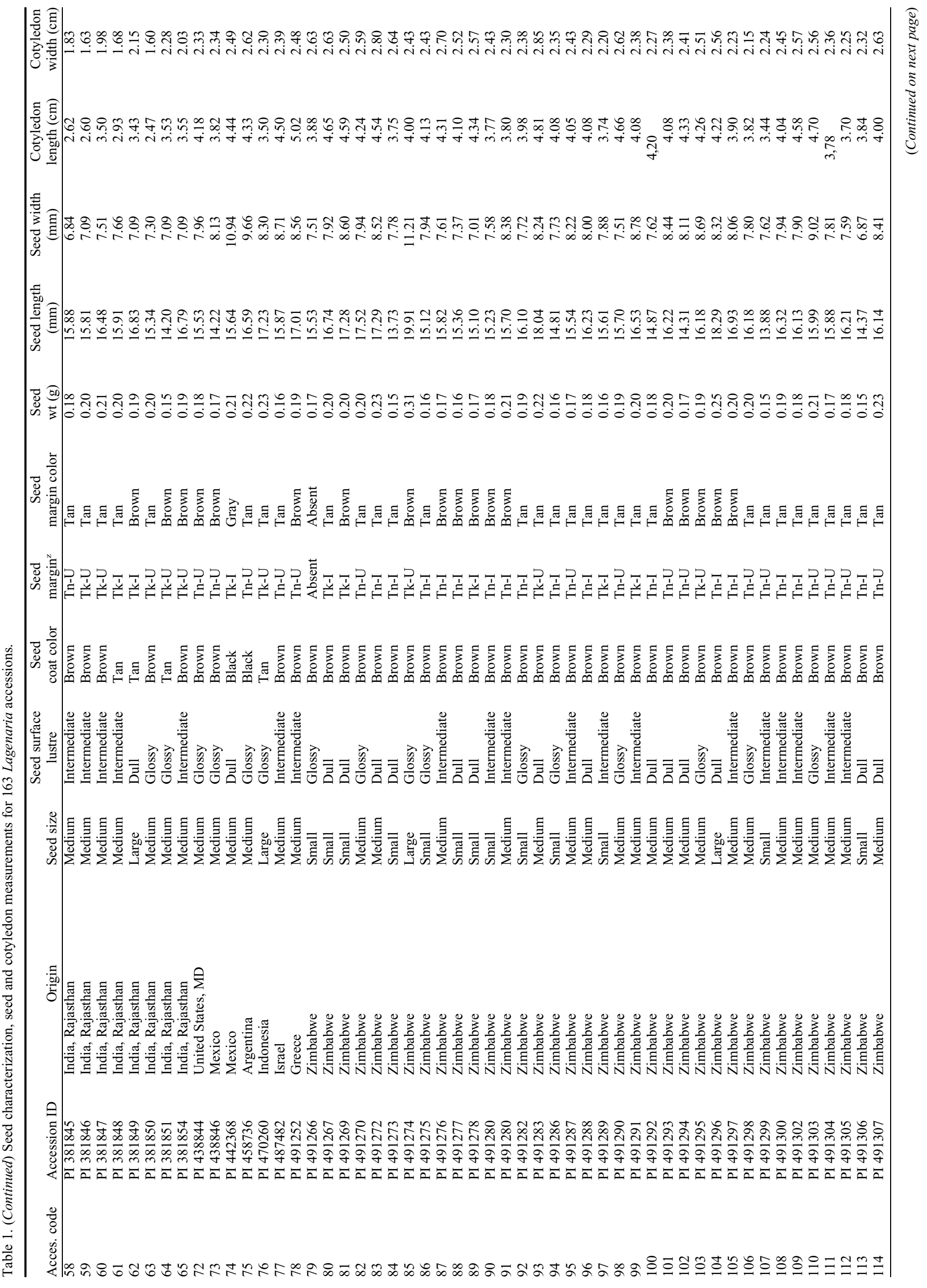




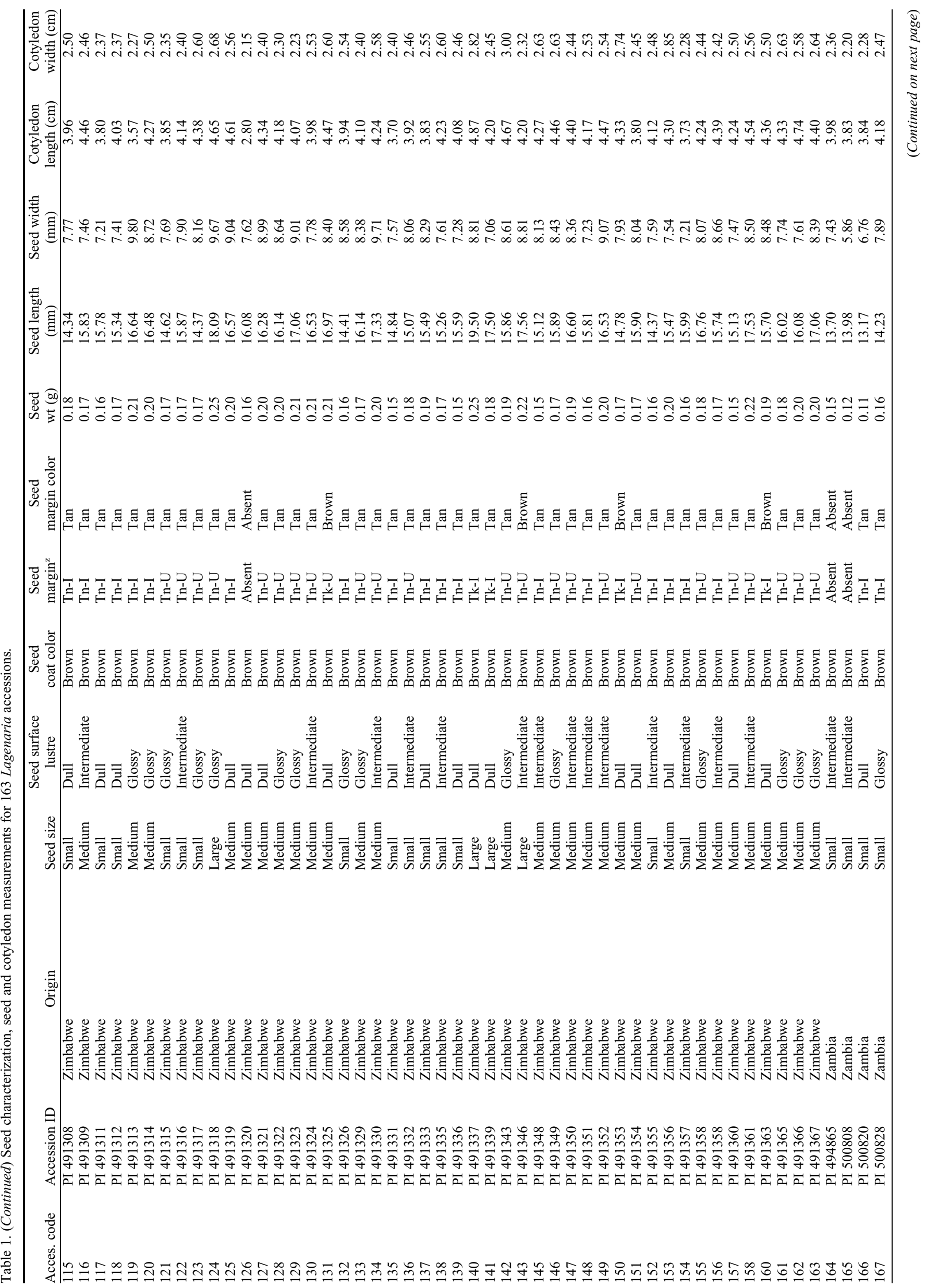




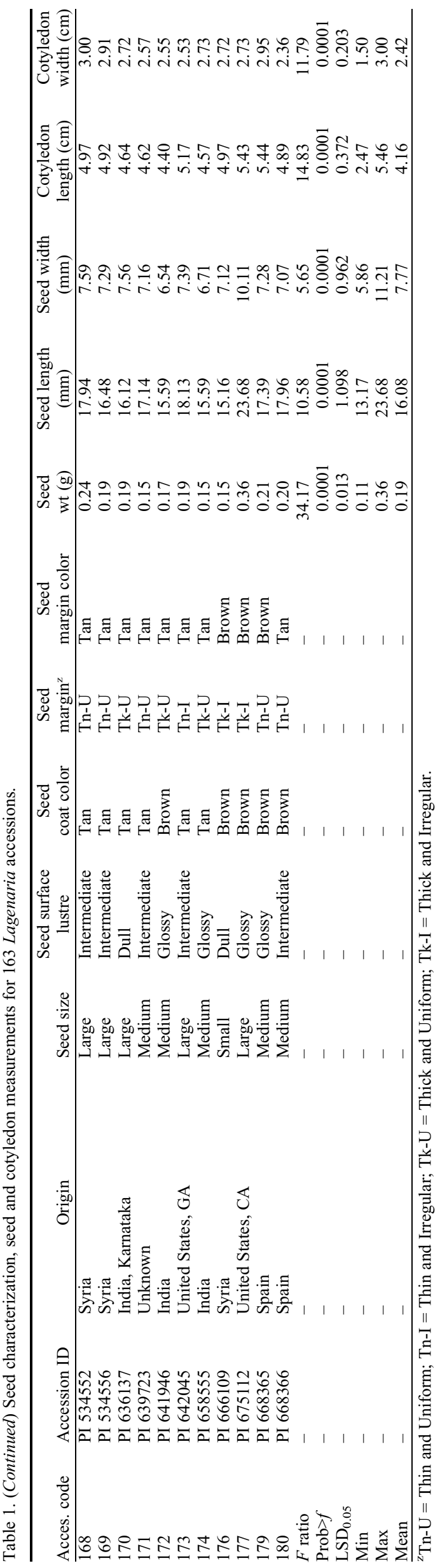

traits: seed weight, seed length, and seed width. Seed dimensions (seed length and width) and seed weight were determined with 10 replications. Seed length and width were measured using a digital caliper, while seed weight was measured using a digital scale. Single-seed weight was determined with 0.01 precision balance.

Seeds of 163 bottle gourd accessions were sown in 48-cell flats filled with a mixture of sand and peat in a 1:1 ratio. The flats were placed in a $37-\mathrm{m}^{2}$ environmentally controlled greenhouse at the North Carolina State University Phytotron after sowing. The greenhouse was set to maintain the air temperature at $26 / 22 \pm 3.0^{\circ} \mathrm{C}$ (day/night), $400 \mathrm{ppm} \mathrm{CO}$, $50 \%$ relative humidity, and a 14 -h photoperiod that was supplemented using sixteen $1000-\mathrm{W}$ metal halide lamps. Plants were watered twice daily: in the morning, with a standard phytotron nutrient solution (Thomas et al., 2005), and in the afternoon, with reverse osmosis water. Seedlings were kept in the greenhouse until the first true leaf stage. Cotyledon length and width of nine plants per treatment combination were measured with a ruler at the stage where the cotyledons were parallel to the ground.

The experiment was a randomized complete block design with nine replications of nine plants each. Data were subjected to analysis of variance (ANOVA) to investigate the differences among accessions. TABULATE and ANOVA procedures of SAS v9.0 statistical software package were used. Mean separations of accessions were tested using Fisher's protected least significant difference at $\alpha=0.05$. Also, the correlation coefficients between all investigated variables, and regressions between significantly related variables, were calculated.

\section{Results}

High variation was observed in all the seed characteristics. Seed size was small in $34(21 \%)$ accessions, medium in $87(53 \%)$, and large in $42(26 \%)$ accessions. Seed surface lustre was observed as dull in $44(27 \%)$ accessions and glossy in $55(34 \%)$ accessions. Sixty-four (39\%) accessions were classified intermediate for this character. Most of the accessions (145 accessions; 89\%) had brown or tan (16 accessions; $10 \%$ ) seedcoat color. Black seedcoat color was determined in only two $(1 \%)$ accessions. While no seed margin was found in only four of 163 accessions, seed margin was observed in the other 159 accessions (57 accessions had thin and uniform seed margin, 43 accessions had thin and irregular, 37 accessions had thick and uniform, and 22 accessions had thick and irregular). Most of the seed margin color was $\tan (105$ accessions; 64\%) and brown (52 accessions; 32\%). Seed margin color was gray in two (1\%) accessions, and absent in four $(3 \%)$ accessions without a seed margin. Other colors were not observed (Table 1).

Highly significant $(P>0.0001)$ differences were observed among the accessions for all measured seed and cotyledon 


\begin{tabular}{|c|c|c|c|c|c|}
\hline & Seed wt (g) & Seed length (mm) & Seed width $(\mathrm{mm})$ & Cotyledon length $(\mathrm{cm})$ & Cotyledon width $(\mathrm{cm})$ \\
\hline Seed width (mm) & & & 1.000 & 0.119 & 0.137 \\
\hline Cotyledon length $(\mathrm{cm})$ & & & & 1.000 & 0.740 \\
\hline
\end{tabular}

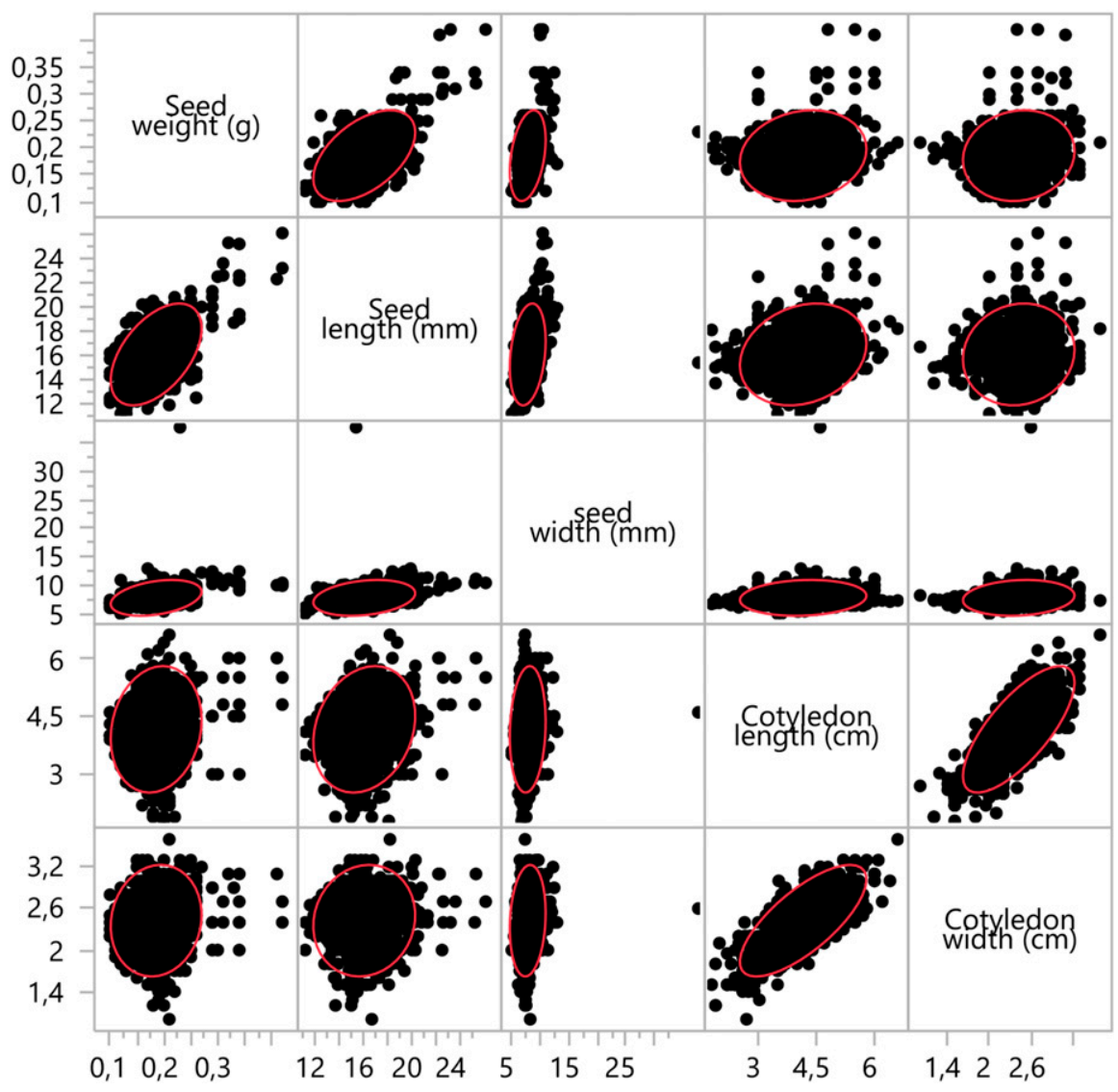

Fig. 1. Correlation diagrams in 163 Lagenaria accessions.
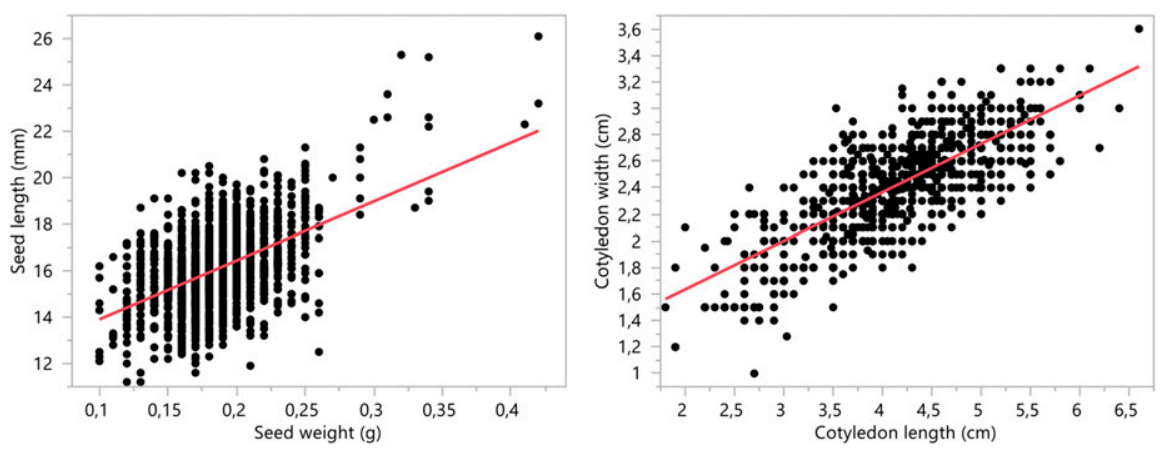

Fig. 2. Regression analysis between seed weight-seed length and cotyledon length-cotyledon width.

characteristics (Table 1). Seed weight ranged from $0.11 \mathrm{~g}$ to $0.36 \mathrm{~g}$. The heaviest seeds were in PI 675112, PI 491274, and PI 491296; accessions with the lowest seed weight were in PI 500820, PI 368638, and PI 368639. In terms of seed length, the average value of 163 accessions was $16.08 \mathrm{~mm}$, the maximum value was $23.68 \mathrm{~mm}$, and the minimum value was $13.17 \mathrm{~mm}$.
Accessions showed variations in seed length in a similar way to seed weight. The accessions with the longest seed length were PI 675112, PI 491274, and PI 491337, and the accessions with the shortest seed length were PI 500820, Grif 970, and PI 494865. For seed width, the average of 163 accessions was $7.77 \mathrm{~mm}$, the maximum was $11.21 \mathrm{~mm}$, and the minimum was $5.86 \mathrm{~mm}$.

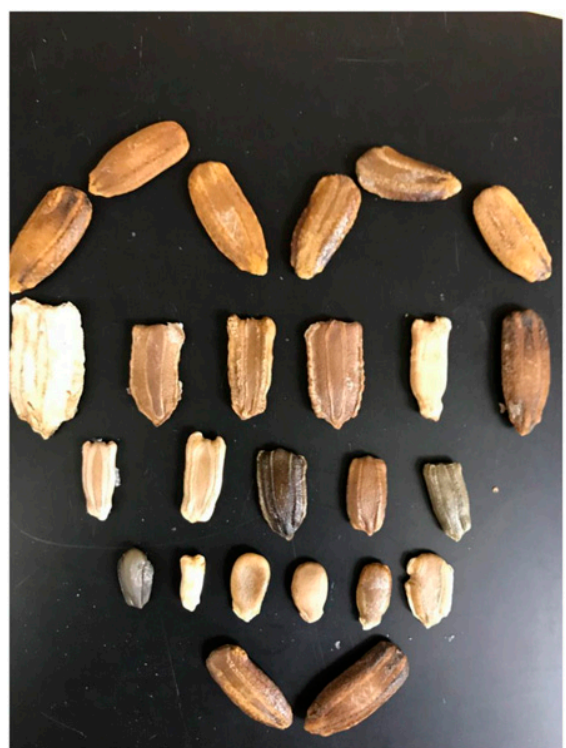

Fig. 3. Variation in seed morphology of USDA Lagenaria seed accessions.

The accessions with the largest cotyledon width were PI 491274, PI 442368, and PI 675112 , and the accessions with the narrowest cotyledon widths were PI 500808, Grif 970, and PI 381830.

Cotyledon measurements after seed sowing for the accessions were also found to be statistically different. The longest cotyledons were in PI 368640, PI 668365, and PI 675112 accessions, while the shortest cotyledon accessions were in PI 381850, PI 381846, and PI 381845. Similarly, the accessions with the widest cotyledons were PI 534552, PI 491343, and PI 668365, while the narrowest were PI 381831, PI 381850, and PI 381846. The average cotyledon length for the 163 accessions was $4.16 \mathrm{~cm}$, and cotyledon width was $2.42 \mathrm{~cm}$. Cotyledon length varied from $2.47 \mathrm{~cm}$ to $5.46 \mathrm{~cm}$, and cotyledon width varied from 1.50 to $3.00 \mathrm{~cm}$.

The highest correlation value $(74.0 \%)$ was determined between cotyledon length and width (Table 2). The correlation between seed weight and seed length was also highly significant $(50.9 \%)$. The correlation between seed weight and seed width was 0.343 , and the correlation between seed length and seed width was 0.259 . The correlation value between seed length and cotyledon length was 0.213 . Correlation values calculated among other parameters were below $20 \%$; the smallest correlation was between seed length and cotyledon width. Correlations for all pairs of traits are shown in Fig. 1. 


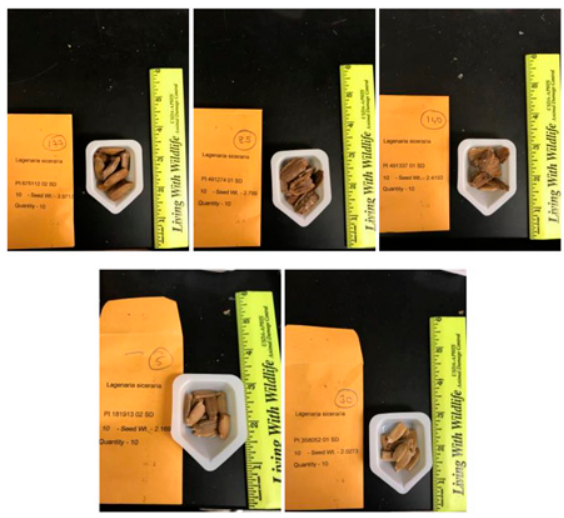

Fig. 4. The longest seeded Lagenaria accessions: 177 (PI 675112; $23.68 \mathrm{~mm}), 85$ (PI 491274; $19.91 \mathrm{~mm}), 140$ (PI 491337; $19.50 \mathrm{~mm}), 5$ (PI $181913 ; 18.41 \mathrm{~mm}$ ), and 30 (PI 358052; $18.34 \mathrm{~mm})$.

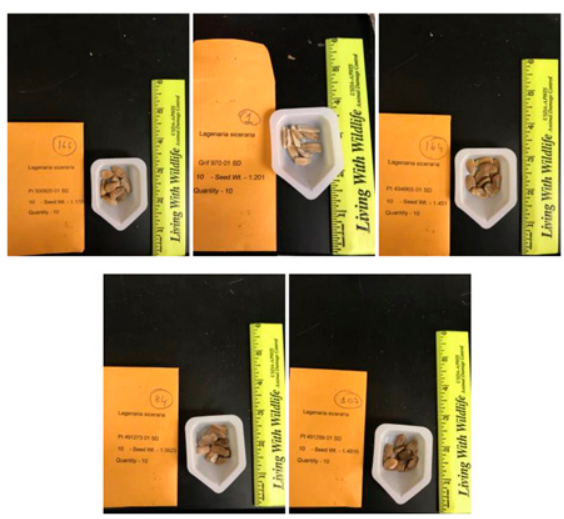

Fig. 5. The shortest seeded Lagenaria accessions: 166 (PI 500820; $13.17 \mathrm{~mm}$ ), 1 (Grif 970; $13.64 \mathrm{~mm}$ ), 164 (PI 494865; $13.70 \mathrm{~mm}), 84$ (PI 491273; $13.73 \mathrm{~mm}$ ), and 107 (PI 491299; $13.88 \mathrm{~mm})$.

Regression analysis between important traits are shown in Fig. 2. The relationship between seed weight and seed length was found to be fully linear. In other words, accessions with heavier seed weight in all accessions had longer seeds. The cotyledon length and cotyledon width also showed a linear distribution, and all accessions were centered around this line. Seed diversity of USDA Lagenaria accessions is shown in Fig. 3, the accessions with the longest seed are presented in Fig. 4, while the shortest seeded accessions are presented in Fig. 5.

\section{Discussion}

Morphological characterization has been used by many scientists as a method of distinguishing differences among plant genetic resources (Solmaz et al., 2007). Seed characteristics are also important for characterization and identification of plants. In this study, which was carried out in 163 bottle gourd accessions of USDA (one of the important gene banks in the world), significant differences were found in terms of seed traits.
A study on South African Lagenaria germplasm on seed size, seed color, and seed margin (Buthelezi et al., 2019), and another study on Turkish germplasm on seed size, seed margin, and seed margin color (Yetişir et al., 2008) showed that Lagenaria had significant diversity in terms of seed characteristics.

Pradhan et al. (2013) reported various physical properties of bottle gourd seeds. Their results revealed that the average length, width, and thickness of seeds were 14.84, 7.44 , and $3.34 \mathrm{~mm}$, respectively. Buthelezi et al. (2019) collected a total of 12 landraces from the northern KwaZulu-Natal region of South Africa and determined seed length to be 14.0 to $23.0 \mathrm{~mm}$, seed width 4.0 to $14.9 \mathrm{~mm}$, and seed weight to be 0.12 to 0.22 g. Yetişir and Aydin (2019) reported the weight of 100 seeds to be 3.7 to $28.06 \mathrm{~g}$, seed length to be 0.7 to $2.18 \mathrm{~cm}$, and seed width to be 0.44 to $1.03 \mathrm{~cm}$ of 22 collected germplasms from different locations of Turkey. According to our research results, seed length ranged from 13.17 to $23.68 \mathrm{~mm}$, seed width ranged from 5.86 to $11.21 \mathrm{~mm}$, seed weight ranged from 0.11 to $0.36 \mathrm{~mm}$ parallel with the results reported by those researchers. Seed size is considered one of the important seed morphology character in Lagenaria and other crops (Chimonyo and Modi, 2013; Kabalci and Sari, 2020; Solmaz and Sari, 2009; Yetişir et al., 2008). Morimoto et al. (2005) and Yetişir et al. (2008) were found to have significant variation and diversity in terms of the seed traits of bottle gourd landraces. Chimonyo and Modi (2013) found significant variation in their morphological examinations of bottle gourds collected from South Africa and Zimbabwe. Yetişir et al. (2005) collected a total of 182 Lagenaria genetic resources from Turkey, and Mashilo et al. (2016) collected a total of 36 landraces from South Africa and reported large seed and cotyledon size variation, depending on accession. In a study where Sharma et al. (2016) compared trailing and traditional growing methods, they found that single-seed weight was $0.16 \mathrm{~g}$ in the trailing method and $0.15 \mathrm{~g}$ in the traditional method. In our study, the seed weights ranged from 0.11 to $0.36 \mathrm{~g}$, probably because we evaluated 163 Lagenaria accessions in our study, and Sharma et al. (2016) used just one cultivar, Pusa Naveen.

Some think that large seeds will be longer and the seedlings developed from those seeds will have larger cotyledons, but no relationship has been reported in the literature regarding the degree of relationship. In a study conducted on 'Galia'-type melon (Yetişir et al., 2004), this relationship was clearly revealed, and significant correlation was found between cotyledon and fruit shape. In our study, the most highly correlated traits were seed weight with seed length $(r=0.51)$, and cotyledon length with cotyledon width $(r=0.74)$.

\section{Conclusions}

As a result of this research, quantitative measurements were made on seeds of Lage- naria spp. from the USDA germplasm collection, and seed sizes were determined. Bottle gourd accessions from four continents showed significant variation for seed biodiversity. In future studies, it may be useful to determine the relationship among traits involving seeds, cotyledons, leaves, and fruit in field and greenhouse conditions. In addition, relationships could be checked with resistance to diseases and pests.

\section{Literature Cited}

Achigan-Dako, E.G., R. Fagbemissi, H.T. Avohou, R.S. Vodouhe, O. Coulibaly, and A. Ahanchede. 2008. Importance and practices of Egusi crops (Citrullus lanatus (Thunb.) Matsum. \& Nakai, Cucumeropsis mannii Naudin and Lagenaria siceraria (Molina) Standl. cv. 'Aklamkpa') in sociolinguistic areas in Benin. Biotechnol. Agron. Soc. Environ. 12:393-403.

Ashita, E. 1927. Grafting of watermelons (in Japanese). Korea (Chosun) Agr. Newsl. 1-9.

Achu, M.B., E. Fokou, C. Tchiegang, M. Fotso, and F.M. Tchouanguep. 2005. Nutritive value of some Cucurbitaceae oilseeds from different regions in Cameroon. Afr. J. Biotechnol. 4:1329-1334.

Bioversity International for Cucurbitaceae. 2007. Guidelines for the development of crop descriptor lists. Bioversity Technical Bulletin Series. Bioversity International, Rome, Italy.

Buthelezi, L.G., S. Mavengahama, and N.R. Ntuli. 2019. Morphological variation and heritability studies of Lagenaria siceraria landraces from northern KwaZulu-Natal, South Africa. Biodiversitas 20(3):922-930, doi: 10.13057/biodiv/ d200342.

Chimonyo, G.P. and A.T. Modi. 2013. Seed performance of selected bottle gourd (Lagenaria siceraria (Molina) Standl.). Amer. J. Expt. Agr. 3(4):740-766, doi: 10.9734/ajea/2013/4114.

Clarke, A.C., M.K. Burtenshaw, P.A. McLenachan, D.L. Erickson, and D. Penny. 2006. Reconstructing the origins and dispersal of the Polynesian bottle gourd (Lagenaria siceraria). Mol. Biol. Evol. 23:893-900.

Given, D.R. 1987. What the conservationist requires of ex situ collections, p.103-116. In: D. Branwell, O. Hamann, V. Heywood, and H. Synge (eds.). Botanic gardens and the world conservation strategy. Academic Press, London.

Harika, M., V.D. Gasti, T. Shantappa, R. Mulge, A.M. Shirol, A.B. Mastiholdi, and M.S. Kulkarni. 2012. Evaluation of bottle gourd genotypes [Lagenaria siceraria (Mol.) Standl.] for various horticultural characters. Karnataka J. Agr. Sci. 25:241-244.

Kabalci, B.B. and N. Sari. 2020. Morphological characterization, plant growth, yield and pod properties of some winged bean [Psophocarpus tetragonolobus] genotypes. Acta Hort. (eds.: N Sari et al.). 1282:363-370. doi: 10.17660/ ActaHortic.2020.1282.54

Koffi, K.K., G.K. Anzara, M. Malice, Y. Dje, P. Bertin, J.P. Baudoin, and I.A. Zoro Bi. 2009. Morphological and allozyme variation in a collection of Lagenaria siceraria (Molina) Standl. from Côte d'Ivoire. Biotechnol. Agron. Soc. Environ. 13:257-270.

Lee, J.M. 1994. Cultivation of grafted vegetables I: Current status, grafting methods and benefits. HortScience 29:235-239.

Levi, A., J. Thies, K.S. Ling, A.M. Simmons, C. Kousik, and R. Hassell. 2009. Genetic diversity among Lagenaria siceraria accessions containing resistance to root-knot nematodes, 
whiteflies, ZYMV or powdery mildew. Plant Genet. Resour. 7(3):216-226, doi: 10.1017/ S1479262109225354.

Loukou, A.L., D. Gnakri, Y. Dje, A.V. Kippre, M. Malice, J.P. Baudoin, and I.A. Zoro Bi. 2007. Macronutrient composition of three cucurbit species cultivated for seed consumption in Côte d'Ivoire. Afr. J. Biotechnol. 6:529-533.

Manandhar, N.P. 2002. Plants and people of Nepal. Timber Press, Portland, OR.

Mashilo, J., H. Shimelis, and A. Odindo. 2016. Genetic diversity of bottle gourd (Lagenaria siceraria (Molina) Standl.) landraces of South Africa assessed by morphological traits and simple sequence repeat markers. S. Afr. J. Plant Soil 33(2):113-124, doi: 10.1080/02571862.2015.1090024.

Moerman, D. 1998. Native American ethnobotany. Timber Press, Portland, OR.

Morimoto, Y., P. Maundu, H. Fujimaki, and $\mathrm{H}$. Morishima. 2005. Diversity of landraces of the white-flowered gourd (Lagenaria siceraria) and its wild relatives in Kenya: Fruit and seed morphology. Genet. Resources Crop Evol. 52(6):737-747, doi: 10.1007/s10722-004-6119-8.

Oda, M. 1995. New grafting methods for fruit bearing vegetables in Japan. Jpn. Agr. Res. Q. 29:187-198.

Pradhan, R.C., P.P. Said, and S. Singh. 2013. Physical properties of bottle gourd seeds. Agr. Eng. Intl. CIGR J. 15(1):106-113.
Schlumbaum, A. and P. Vandorpe. 2012. A short history of Lagenaria siceraria (bottle gourd) in the Roman provinces: Morphotypes and archaeogenetics. Veg. Hist. Archaeobot. 21:499-509, doi: 10.1007/s00334-011-0343$\mathrm{x}$.

Sharma, R.K., B.S. Tomar, S.P. Singh, and A. Kumar. 2016. Effect of growing methods on seed yield and quality in bottle gourd (Lagenaria siceraria). Indian J. Agr. Sci. 86(3):373-378.

Sivaraj, N. and S.R. Pandravada. 2005. Morphological diversity for fruit characters in bottle gourd germplasm from tribal pockets of Telangana region of Andhra Pradesh, India. Asian Agrihist. 9(4):305-310.

Solmaz, I. and N. Sari. 2009. Characterization of watermelon (Citrullus lanatus) accessions collected from Turkey for morphological traits. Genet. Resources Crop Evol. 56:173-188, doi: 10.1007/s10722-008-9353-7.

Solmaz, I., N. Sari, and S. Kasapoglu. 2007. Morphological characterization of watermelon genetic resources collected from Central Anatolia and Mediterranean regions. Turkey 5th National Horticultural Congress, 4-7 Sept. 2007, Erzurum, 236-241.

Thomas, J.F., R.J. Downs, and C.H. Saravitz. 2005. Phytotron procedural manual for controlled environment research at the southeastern plant environment laboratory. NCARS Tech. Bul. 244 (revised).

Xu, P., S. Xu, X. Wu, Y. Tao, B. Wang, S. Wang, D. Qin, Z. Lu, and G. Li. 2014. Population genomic analyses from low-coverage RADSeq data: A case study on the non-model cucurbit bottle gourd. Plant J. 77:430-442, doi: $10.1111 /$ tpj.12370.

Yetişir, H. and N. Sari. 2003. Effect of different rootstock on plant growth, yield and quality of watermelon. Austral. J. Expt. Agr. 43:12691274, doi: 10.1071/EA02095.

Yetişir, H., N. Sari, and I.E. Ekbic. 2004. Association between plant and fruit characteristics in dihaploid cantaloupe melon (Cucumis melo var. cantalupensis). Indian J. Agr. Sci. 74(7):379-381.

Yetişir, H., M. Sakar, and S. Serce. 2008. Collection and morphological characterization of Lagenaria siceraria germplasm form the Mediterranean region of Turkey. Genet. Resources Crop Evol. 55(8):1257-1266, doi: 10.1007/ s10722-008-9325-y.

Yetişir, H. and A. Aydin. 2019. Fruit, seed characteristics and seed yield of some bottle gourds (Lagenaria siceraria Molina Standl.) genotypes from Turkish germplasm. KSU J. Agr. Nat. 22(Suppl. 2):272-281, doi: 10.18016/ ksutarimdoga.vi.568008. 